REGULAR ARTICLE

\title{
DETECTION OF ADULTERATION AND QUALITY EVALUATION OF RAW MILK COLLECTED FROM LOCAL MARKETS IN BANGLADESH
}

\author{
ANWARUL ISLAM"1, TOUHIDUZZAMAN SARKER², ADHITA SRI PRABAKUSUMA3, IMRUL \\ HASAN RUSSEL4, SHAHIDUL ISLAM ${ }^{*}$
}

\author{
${ }^{1}$ Animal Science, Bangladesh Agricultural University, Mymensingh, Bangladesh \\ ${ }^{2}$ Department of Dairy Science, Bangladesh Agricultural University, Bangladesh \\ 3Department of Food Technology, Universitas Ahmad Dahlan, Indonesia \\ 4Department of Finance, Asian University of Bangladesh \\ 5Department of Plant Pathology, Yunnan Agricultural University, Kunming, China
}

\begin{abstract}
This experiment was aimed to detect adulteration and assess the quality of raw milk which were collected from various local markets in Bangladesh. The samples of the raw milk were collected from Narikali Bazar, Sofir Mia Bazar and Sokal Bazar of Jamalpur district in Bangladesh. Parameters were used to detect adulteration such as presence of Formalin, Starch, Cane Sugar, and coloring agent, and to screen the qualities of the samples on the basis of physical tests (color, flavor, taste, texture and specific gravity), chemical tests [acidity, fat, ash, lactose, protein, TS and SNF]-and microbiological tests. From the physical test, it was found that all the samples were yellowish white in color, normal in taste and flavor and free flowing fluid in case of texture. All of the raw milk samples did not fulfill the legal standard of milk composition. However, raw milk samples of Sokal Bazar were higher in fat, protein, lactose, SNF and TS contents than the other two samples. Microbiological parameters also remained high in all raw milk samples than the standard. It was observed that no adulteration was found in any of the collected raw milk samples. This study revealed that hygiene condition did not properly maintain during milking and transportation of the raw milk supplied in the local markets.
\end{abstract}

Keywords: Raw milk, Adulteration, Food, Milk quality, Bangladesh

\section{INTRODUCTION}

As a third world country, Bangladesh suffers from malnutrition severely. It has an average of 1.47 lakh square kilometers with a population of 154 million, of which 28 percent live in urban and 72 percent in rural areas. The sources of a balanced diet are very challenging here for the people. Hasan and Rakib [1] reported that the average milk production per cow per year is about $2190 \mathrm{~kg}$ in developed countries, $1220 \mathrm{~kg}$ in Asia whereas $206 \mathrm{~kg}$ in Bangladesh. Milk is the lacteal secretion of a healthy animal. It can be obtained two weeks before or one week after calving. It usually contains $3.5 \%$ fat and $8.5 \%$ not fat solids with no colostrum [2]. In Bangladesh, there is no prominent organization which deals the milk production in rural areas with its distribution to market and milk processing organization. It is usually done by middleman [3]. Most of the dairy farmer's livelihood depends on rearing cow and selling milk [4]. It is very common in rural areas by which dairy farmer of rural area earn money by selling milk and it helps to reduce their poverty and food insecurity $[5,6$,
7]. Women farmer also can rear milking cows in the riverine island char areas of Bangladesh which empowers themselves [1, 8, 9]. There are a few organizations especially Milk Vita and other dairy farm where excess milk is readily available as a result it is failed to get attention from concerned authorities $[10,11]$. The dairy farmer needs capital for purchasing healthy cow and rearing so that the production can be increased with improved milk quality. The capital can be borrowed from commercial banks of Bangladesh but it needs special attention of government [12, 13].

Milk is the heterogeneous product and an almost complete and well-balanced food for the newly born infant or animal $[14,15]$. Farkye [16] and Javaid et al. [17] reported that it is a necessary item of daily diet. Milk-fat has nutrias value which is easily consumable and a source of energy. It also helps in lactose assimilation [18]. The protein of milk contains three major proteins viz lactoglobulin, lactalbumin, and casein. Among them, Casein is the principal protein component of milk and tryptophan and

Received 18 December 2017; Accepted 13 April 2018

*Corresponding Author

Shahidul Islam

Department of Plant Pathology, Yunnan Agricultural University, Kunming, China

Email: scholarzone.cn@yahoo.com

( $T$ This article is open access and licensed under the terms of the Creative Commons Attribution License (http://creativecommons.org/licenses/by/4.o/) which permits unrestricted, use, distribution and reproduction in any medium, or format for any purpose, even commercially provided the work is properly cited. Attribution - You must give appropriate credit, provide a link to the license, and indicate if changes were made. 
lysine also are also major amino acid elements in milk. Besides glutamic acid present in cow's milk are 3 times higher than in human milk, which results in a reduction of cholesterol level in blood. The oratic acid of milk protein improves liver detoxification. Another content taurine is responsible for the development of immature brain tissue of mammalian young. Lactose is the major element of milk which helps to utilize calcium properly and good food elements for baby [1]. Moreover, galactose the special component of lactose is essential for the nervous system. Lactose has an influence on the growth and development of baby and adult. More over some are present in large quantities than human requirement [19]. Milk also contains Vitamin E, which cures heart disease. Khan et al. [20] reported that in Bangladesh, Milk collector (Goala) collects milk from rural and urban areas and sell it to the market. It is main professions of so many people who lead their livelihood on it. Goalas purchase milk from different smallholder dairy farmers and local markets. Besides dairy farmer sells their milk by themselves in the local market and earn money which helps to reduce poverty and improving food security. There is some established milk processing center in Bangladesh which collects milk from dairy farmers through milk collector and process it for future use by packaging. Islam et al. [21] found the supplied milk occasionally adulterated. A successful dairy operation requires knowledge of microorganisms which is usually available in milk [1]. The consumer usually suffers for milk adulteration so they want to get fresh, clean and pure milk and pathogen-free [22, 23]. Global data indicate that during the last $20 \mathrm{y}$, the world has witness spectacular expansion in the livestock industries. Farrell [24] reported that Milk is expected to increase by $64 \%$ in the world by the year 2020. So, it is necessary to increase milk production to mitigate the requirement. Milk can undergo spoilage due to the action of various microorganisms. Undesirable bacteria in milk causes some defects like flavor deterioration, discoloration, souring, and gassiness. Lactose is broken down to glucose and galactose by microbial enzyme lactase and finally, lactic acid is produced from glucose. The adulteration of milk is usually done by adding water, sugar and flour. Adulteration can cause health problems in consumers. For this reason, it is an important matter to know technical knowledge about how milk is adulterated? The study was undertaken with the aim of detecting adulteration and evaluating the hygienic quality (physical, chemical and microbiological) of raw milk from local markets of Jamalpur district in Bangladesh. The specific objectives are (a) to determine the type of adulterants and frequency of adulteration in the raw milk supplied, and (b) to evaluate the quality of raw milk in terms of physical, chemical and microbiological parameters.

\section{MATERIALS AND METHODS}

\section{Site selection and collection of sample}

The experiment was conducted by the milk samples which were collected from different local markets of Jamalpur Upazila in Bangladesh. Adulteration, organoleptic, chemical, and microbiological test was observed [25]. The samples of milk were collected from the 3 different places of Jamalpur Upazila. These samples were collected from the following places: Narikali Bazar, Sofir Mia Bazar and Sokal Bazar of Jamalpur Upazila of Bangladesh. The present experiment was conducted at Dairy Science laboratory of the Department of Dairy Science, Bangladesh Agricultural University during the period from 1st July to 13th November 2013. Three local markets namely Narikali Bazar, Sofir Mia
Bazar, and Sokal Bazar were selected for this experiment. The pots were cleaned properly which used for sample collections. Three times sample and three samples in each time were collected from these local markets.

\section{Analysis of the samples}

Different tests related to detection of adulteration, organoleptic, chemical [25] and microbiological parameters were conducted for determining adulteration and quality status [27].

\section{Adulteration test}

Adulteration tests were done through starch, formalin, cane sugar and coloring agents as follows.

\section{Organoleptic evaluation}

a) Color: The judging of color was done by eye for the organoleptic test. The color of milk is a blend of individual effects produced by Carotene, which imparts a yellowish color.

b) Flavor: Flavor may be detected by sniffing the products before placing in the mouth and also while in the mouth.

c) Taste: The sample was placed in the mouth, rolled around in the mouth to come in contact with the taste buds located on the various portion of the tongue.

d) Texture: The judging of the texture of milk sample was also done by eye.

\section{Chemical tests}

Acidity [25], Fat test [49], Protein percentage [1], Ash content [28], total solids [28], Solids-not-fat (SNF) [25] Specific gravity [25] were tested by following standard methods.

The lactose content was estimated by the following formula: Lactose content of milk = SNF\%-(Protein\%+Ash \%)

\section{Microbiological tests and statistical analysis}

The experiment followed the procedures of American Public Health Association for the determination of total viable bacteria and the detection and enumeration of coliform bacteria [26]. It employed Completely Randomized Design (CRD) and done a subsequent test like one-way analysis of variance test by using MSTATC package software. Least Significance Difference (LSD) test was administered for ranking the means.

\section{RESULTS AND DISCUSSION}

In this experiment, milk samples collected from three local markets of Jamalpur town i.e. from Narikali Bazar (A), Sofir Mia Bazar (B), and Sokal Bazar (C) were analyzed to detect adulteration and monitor their quality. Results obtained from this experiment are discussed below:

\section{Tests for adulteration}

\section{Starch test}

Akirul [29] showed negative results of the starch test for all the samples collected from Muktagacha Upazila of Mymensingh District in Bangladesh. Rashedul [30] also found the negative results of the starch test for all milk samples collected from Fulbaria Upazila, Mymensingh. Lateef et al. [31] reported that milk dealers maximize their profit margin by dilution and extraction of valuable milk fat. Various products are made by using cream which is extracted from milk [32]. 
Table 1: Adulteration test results of collected raw milk samples

\begin{tabular}{llll}
\hline Items & Narikali Bazar & Sofir Mia Bazar & Sokal Bazar \\
\hline Starch & Negative & Negative & Negative \\
Formalin & Negative & Negative & Negative \\
Cane sugar & Negative & Negative & Negative \\
Colouring Agents & Negative & Negative & Negative \\
\hline
\end{tabular}

\section{Formalin test}

The formalin test showed negative results. Safi [33] found the negative results formalin test for all the collected milk samples of Mymensingh, Bangladesh. Rashedul [30] also reported the negative results of formalin test for all milk samples collected from Mymensingh, Bangladesh.

\section{Cane sugar test}

The results for cane sugar test of all milk samples showed negative results. Addition of sugar in milk is a very common adulteration problem in dairy industry [34] and the SNF content in milk is increased by the addition of sugar and only $0.2 \%$ addition increase lactometer reading by one degree of $60{ }^{\circ} \mathrm{F}$. Zia [35] observed that cane sugar is added in milk to increase the solids-not-fat content of milk after addition of water.

\section{Test for the coloring agent}

All the milk samples showed negative results in case of the coloring agent. Akirul [29] showed negative results of coloring agent for all the samples collected from Mymensingh, Bangladesh.

\section{Physical parameters}

The physical parameters were measured after sample collection (table 1). These parameters were a mainly organoleptic test (color, flavor, taste, texture) and specific gravity of the raw milk samples [36].

\section{Organoleptic evaluation}

\section{Color and flavor}

All samples were yellowish white in color. Most of the samples agree with Rashedul [30] who reported that the color of the milk sample collected from local market were yellowish white and same as Monem [37]. All the collected milk samples were normal in flavor [38].

\section{Taste}

The taste of all milk samples was normal. Bari [38] showed that normal taste of milk collected from BAU Dairy Farm in where milking had been done hygienically. Safi [33] found the taste was slightly sweet and Rashedul [30] reported slightly sweet in taste for all milk samples of Mymensingh, Bangladesh.

\section{Texture}

The texture of raw milk sample was examined when milk was bought. All samples were normal texture (Free flowing fluid). Rashedul [30] found the texture of raw milk sample were normal and same as Safi [33]. The physical quality of raw milk collected three local markets of Jamalpur Sadar were almost similar with a few variations in terms of physical qualities.

\section{Chemical parameters}

The chemical parameters of total solids $(\mathrm{g} / \mathrm{kg})$ raw milk samples such as specific gravity, acidity\%, fat $(\mathrm{g} / \mathrm{kg})$, protein $(\mathrm{g} / \mathrm{kg})$, lactose $(\mathrm{g} / \mathrm{kg})$, ash $(\mathrm{g} / \mathrm{kg})$, total solids $(\mathrm{g} / \mathrm{kg})$, solids-not-fat $(\mathrm{g} / \mathrm{kg})$ were shown in the table 2 .

\section{Specific gravity}

The specific gravity of sample Narikali Bazar, Sofir Mia Bazar, and Sokal Bazar were 1.028 $\pm 0.00,1.027 \pm 0.00$, and1.027 \pm 0.00 respectively (table 2). There was no significant difference within the specific gravity of different milk samples. The specific gravity of milk obtained from Narikali Bazar was higher than milk of another market. Islam et al. [21] found a higher specific gravity of cow's milk from BAU Dairy Farm than local markets. In another experiment, Salam [45] found 1.027 \pm 0.00 average specific gravity for milk of Bhaghabarighat Dairy Plant. Rahman [44] reported $1.023 \pm 0.00$ for the same plant. Mahedi [40] found that $1.024 \pm 0.02$ average specific gravity for local market milk of Mymensingh, Bangladesh. Monem [37] found $1.026 \pm 0$. for local market milk of Bogra, Bangladesh. Milk fat has some influence on the specific gravity of milk. Specific gravity mostly depends on the TS content and increases when the TS content rises.

\section{Acidity percentage}

From the table2, acidity percentage of sample Narikali Bazar, Sofir Mia Bazar, and Sokal Bazar were 0.15 \pm 0.00 , $0.16 \pm 0.01$ and $0.16 \pm 0.01$ respectively. There was no significant difference in the acidity percentage of milk collected from local markets. Acidity percentage of milk sample of Sofir Mia Bazar was higher than other markets. Asaduzzaman [39] reported the average percentage of acidity of milk available at Mymensingh district of Bangladesh was $0.15 \pm 0.00$. In another experiment, Mahedi [40] found $0.15 \pm 0.00$ average percentage of acidity. Microbial activities or enzymatic reaction is responsible for higher acidity in milk [41]. From the normal acidity value of milk obtained from three markets, that means, all the milk samples were fresh during an experiment on the laboratory.

\section{Fat content}

The fat content of sample Narikali Bazar, Sofir Mia Bazar, and Sokal Bazar were $37.50 \pm 0.50,38.66 \pm 0.29$, and $38.88 \pm 0.29$ respectively (table 2). There was a significant difference within the fat content of different milk samples [42]. The highest value of fat was obtained from the milk of Sokal Bazar than other sources in this experiment. The standard value of BSTI-(2002) for the average fat content of milk is $35 \mathrm{~g} / \mathrm{kg}$. Asaduzzaman [39] found $44.35 \mathrm{gm} / \mathrm{kg}$ and Safi [33] found $31.5 \mathrm{gm} / \mathrm{kg}$ average fat content of milk for Mymensingh town of Bangladesh. 
Table 2: Summary of the results $(\operatorname{mean} \pm \mathrm{SD})$ of physical parameters of raw milk samples

\begin{tabular}{lllll}
\hline Parameter and sample number & Narikali bazar & Sofir mia bazar & Sokal bazar & Level of significance \\
\hline Flavor (45) & $41.33 \pm 1.15$ & $40.33 \pm 0.58$ & $42.00 \pm 1.00$ & Non-significant \\
Appearance (5) & $3.33 \pm 0.58$ & $3.00 \pm 1.00$ & $3.66 \pm 0.58$ & Non-significant \\
\hline
\end{tabular}

Table 3: Summary of the results (mean \pm SD) of chemical parameters of raw milk

\begin{tabular}{lllll}
\hline Parameters & Narikali bazar & Sofir mia bazar & Sokal bazar & Level of significance \\
\hline Specific gravity & $1.028 \pm 0.00$ & $1.027 \pm 0.00$ & $1.027 \pm 0.00$ & NS \\
Acidity (\%) & $0.15 \pm 0.00$ & $0.16 \pm 0.01$ & $0.16 \pm 0.01$ & NS \\
Fat $(\mathrm{g} / \mathrm{kg}$ & $37.50 b \pm 0.50$ & $38.66 \mathrm{a} \pm 0.29$ & $38.83 \mathrm{a} \pm 0.29$ & $* *$ \\
Protein $(\mathrm{g} / \mathrm{kg})$ & $35.86 \pm 0.85$ & $36.93 \pm 1.50$ & $37.16 \pm 1.04$ & $\mathrm{NS}$ \\
Lactose $(\mathrm{g} / \mathrm{kg})$ & $42.70 \pm 0.96$ & $42.43 \pm 2.93$ & $44.66 \pm 1.76$ & $\mathrm{NS}$ \\
Ash $(\mathrm{g} / \mathrm{kg})$ & $6.66 \pm 0.21$ & $7.23 \pm 0.93$ & $6.83 \pm 0.58$ & $\mathrm{NS}$ \\
TS $(\mathrm{g} / \mathrm{kg})$ & $122.73 \pm 0.91$ & $125.26 \pm 5.33$ & $127.50 \pm 1.80$ & $\mathrm{NS}$ \\
SNF $(\mathrm{g} / \mathrm{kg})$ & $85.23 \pm 2.33$ & $86.60 \pm 5.05$ & $86.66 \pm 1.76$ & $\mathrm{NS}$ \\
\hline
\end{tabular}

a,b,c In a row fig. with the same superscription do not differ significantly whereas fig. with dissimilar superscription(a, b, c) differ significantly: ${ }^{*} \mathrm{P}<0.01, \mathrm{NS}=$ Non-significant.

\section{Protein content}

From the table 2, it is found that protein content of sample Narikali Bazar, Sofir Mia Bazar, and Sokal Bazar were $35.86 \pm 0.85,36.93 \pm 1.50$ and $37.16 \pm 1.04$ respectively. The average protein content was higher in Sokal Bazar compared to other which was due to nutritional level and genotypic variation of cows.

\section{Lactose content}

Lactose content of sample Narikali Bazar, Sofir Mia Bazar, and Sokal Bazar were 42.70 $\pm 0.96,42.43 \pm 2.93$, and $44.66 \pm 1.76$ respectively (table 2 ). There was no significant difference between the lactose content of different milk samples [1]. Milk sample of Sokal Bazar resumed more lactose compared to other sources. Mahedi [40] found $39.13 \pm 3.2,39.05 \pm 2.05$, and $38.61 \pm 3.61 \mathrm{~g} / \mathrm{kg}$ for milk of Mymensingh town of Bangladesh [25]. So, the finding of the results in this study was higher [43].

\section{Ash content}

Ash content of sample Narikali Bazar, Sofir Mia Bazar, and Sokal Bazar were 6.66 $\pm 0.21,7.23 \pm 0.93$, and $6.83 \pm 0.58$ respectively. The ash content of different of milk samples had no significant difference. The percentage of ash in cow's milk collected from mid lactation was $0.75 \%$ [43]. Ash content of milk sample of Sofir Mia Bazar almost met the standard value and lower value in case of Narikali Bazar and Sokal Bazar.

\section{Total solids (TS) content}

Average total solids (TS) content of milk samples were $122.73 \pm 0.91,125.26 \pm 5.33$ and $127.50 \pm 1.80$ respectively. The TS content of milk collected from local markets of Jamalpur Sadar, and Sokal Bazar had higher total solids content than other sources. Rahman [44] found 11.49, 10.78, 10.72 and $12.91 \%$ TS content for milk of Manikgonj Chilling Centre, Tangail Chilling Centre, Takerhat Pasteurization Plant and Bagliabari Dairy Plant respectively.

\section{SNF content}

SNF content of sample Narikali Bazar, Sofir Mia Bazar, and Sokal Bazar was 85.23 $\pm 2.33,86.60 \pm 5.05$ and
$86.66 \pm 1.76$ respectively (table 2 ). The SNF content of milk samples had no significant difference. Islam et al. [21] also reported lower SNF contents in local market milk than that of the milk from BAU Dairy Farm, Mymensingh. Rahman [44] reported that the average SNF content of mixed milk collected from different primary co-operative society under Baghabari Dairy Plant was 7.69\% [25]. Mahedi [40] found 7.7 average SNF percentage.

\section{Microbiological test}

\section{Total viable bacterial count}

The average values of the total viable count of sample Narikali Bazar, Sofir Mia Bazar and Sokal Bazar were $8.3 \pm 1.25 \times 105,10.0 \pm 1.0 \times 105,7.6 \pm 0.76 \times 105$ respectively. There was no significant difference among the samples. Average total viable counts/ml for "Grade A" raw milk is not exceeding 200000 for milk to be pasteurized. In this experiment, the comparatively higher viable bacterial count found in Sofir Mia Bazar milk sample which may be due to poor hygienic milking and utensils [43]. On the other hand, total viable count collected form Sokal Bazar was slightly lower which due to the proper hygienic condition. High bacterial density of above mentioned three local markets milk might be due to unhygienic milking and handling. Monem [37] showed that the total viable bacterial count of Bogra town range from $10 \times 105$ to $19 \times 105$. So, the finding of the results in this study were lower.

\section{Coliform count}

The average values of coliform counts of sample Narikali Bazar, Sofir Mia Bazar, and Sokal Bazar were $63.33 \pm 15.28,70.00 \pm 20.00$ and $60.00 \pm 10.00 \mathrm{CFU} / \mathrm{ml}$ respectively. The coliform counts/ml of different milk samples had no significant difference and the coliform counts $/ \mathrm{ml}$ of milk samples were slightly higher. It is for poor hygienic milking, improper cleaning and unhygienic handling $[46,47,48]$. Rashedul [30] reported that coliform count of raw milk samples of Fulbaria Upazila in Mymensingh District ranges from 70 to 120. 
Table 4: Average total viable count (TVC) and coliform count of bacteria in raw milk samples

\begin{tabular}{lllll}
\hline Parameter & Narikali bazar & Sofir mia bazar & Sokal bazar & Level of significance \\
\hline Total viable count $\mathrm{CFU} / \mathrm{ml}$ & $8.3 \pm 1.25 \times 105$ & $10.0 \pm 1.0 \times 105$ & $7.6 \pm 0.76 \times 105$ & Non-significant \\
Coliform count $\mathrm{CFU} / \mathrm{ml}$ & $63.33 \pm 15.28$ & $70.00 \pm 20.00$ & $60.00 \pm 10.00$ & Non-significant \\
\hline
\end{tabular}

\section{CONCLUSION}

The research was aimed to determine the adulteration and evaluate the quality (physical, chemical and microbiological) of raw milk. Total 27 milk samples were collected from three markets taking 9 samples from Narikali Bazar, 9 samples from Sofir Mia Bazar, and 9 samples from Sokal Bazar. This study revealed from chemical parameters that milk samples of Narikali, Sofir Mia and Sokal Bazar had mean acidity (0.15 \pm 0.00 , $0.16 \pm 0.01,0.16 \pm 0.01)$; fat $(37.50 \pm 0.50,38.66 \pm 0.29$, $38.83 \pm 0.29 \mathrm{~g} / \mathrm{kg})$; protein $(35.86 \pm 0.85,36.93 \pm 1.50$, $37.16 \pm 1.04 \mathrm{~g} / \mathrm{kg}) ; \quad$ lactose $(42.70 \pm 0.96, \quad 42.23 \pm 2.93$, $44.66 \pm 1.76 \mathrm{~g} / \mathrm{kg}) ;$ ash $(6.66 \pm 0.21,7.23 \pm 0.93,6.83 \pm 0.58$ $\mathrm{g} / \mathrm{kg}) ; \mathrm{TS}(122.73 \pm 0.91,125.26 \pm 5.33,127.50 \pm 1.80 \mathrm{~g} / \mathrm{kg})$; SNF (85.23 $\pm 2.33,86.60 \pm 5.05,86.66 \pm 1.76 \mathrm{~g} / \mathrm{kg})$; specific gravity $1.028 \pm 0.00, \quad 1.027 \pm 0.00$ and $1.027 \pm 0.00$ respectively. The fat content of samples had significant difference while no significant differences in case of other parameters among three markets. However, in adulteration test, all of the test results were negative. No adulteration was found in the sample, though there was fluctuation in parameters (fat, protein, ash, lactose). It was visualized after inspection that all the market samples were yellowish white in color, normal in taste and flavor and free flowing fluid in case of texture. The specific gravity was more or less similar. From the overall experiment, it can be concluded that Milk collected from Sokal Bazar milk was superior in case of Fat, Protein and Lactose content than any other markets of collected milk sample. It is necessary to train farmers about the hygienic aspects of milk production and marketing for the production of better quality milk. A person should be honest who is involved in milk marketing as well as Dairy industry for ensuring safe consumption of milk to the consumers.

\section{REFERENCES}

1. Hasan T, Rakib RH. Physiochemical and Microbiological Quality Assessment and Detection of Adulterants of Raw Milk Available in Nakla. 2016;14: 210-217.

2. Żywica R, Banach JK, Kiełczewska K. An attempt of applying the electrical properties for the evaluation of milk fat content of raw milk. $J$ Food Eng. 2012;111:420-424.

3. Sarker, MNI (2016a). Poverty of Island Char Dwellers in Bangladesh. Hamburg, Diplomica Publishing GmbH, Germany. http://www. anchorpublishing.com/e-book/318628/poverty-of-islandchar-dwellers-in-bangladesh.

4. Sarker MNI, Barman SC, Islam M, Islam R. Role of lemon (Citrus limon) production on livelihoods of rural people in Bangladesh. J Agric Econ Rural Dev. 2017;2:167-175.

5. Sarker MNI, Kashem MA, Rahman, MZ. Poverty alleviation of rural people through Chars Livelihoods Program. J Bangladesh Socioety Agric Sci Technol. 2007;(3and4):203-208.

6. Sarker MNI, Ali MA, Islam MS. Causes and possible solutions of poverty perceived by char dwellers in Bangladesh. Int J Nat Soc Sci. 2015;2:37-41.
7. Sarker MNI. Knowledge, Adoption and Constraint analysis of Chilli Technology in Char Area of Bangladesh. Int $J$ Ecol Dev Res. 2016;1:16-18.

8. Sarker MNI, Sultana A. An Investigation into the Status of Riverbank (Char) Women Dwellers in Bangladesh. Int $J$ Rural Dev Environ Heal Res. 2017;1:86-92.

9. Sarker MNI. Causes and possible solutions of seasonal food insecurity (Monga) perceived by char dwellers in Bangladesh. Int J Ecol Dev Res. 2016;1:2-9.

10. Grandin T. Evaluation of the welfare of cattle housed in outdoor feedlot pens. Vet Anim Sci. 2016;12(October):23-28.

11. Sarker MNI. Role of Banks on Agricultural Development in Bangladesh. Int $J$ Ecol Dev Res. 2016;1:10-15.

12. Sarker MNI, Ali MA, and Islam MS. Causes and possible solutions of poverty perceived by char dwellers in Bangladesh. Int $J$ Nat Soc Sci. 2015;2: 3741.

13. Sarker MNI, Bingxin Y, Sultana A, Prodhan AS. Problems and challenges of public administration in Bangladesh: pathway to sustainable development. Int $J$ Public Adm Policy Res. 2017;3:16-25.

14. Abdelfatah EN, El-araby IE, Mohamed AA. Identification of Species Adulteration in Raw Milk and Butter Using Polymerase Chain Reaction-Restriction Fragment Length Polymorphism. System. 2015;15:332-338.

15. Jafarpour A. Feasibility of manufacture and investigation of physicochemical properties of camel milk-based ice cream. J Sci Agric. 2017;1:300.

16. Farkye NY. Other Enzymes and Proteins in Advanced Dairy Chemistry. Volume 1,3rd edition, New York, USA. 2003;75-79.

17. Javaid SB, Gadahi JA, Khaskeli M, Bhutto MB, Kumbher S and Panhwar AH. Physical and chemical quality of market milk sold at Tandojam, Pakistan. Pakistan Veterinary Journal. 2009;29: 27-31.

18. Brandao MP, Neto MG, de Carvalho dos Anjos V, Bell MJV. Detection of adulteration of goat milk powder with bovine milk powder by front-face and time resolved fluorescence. Food Control. 2017;81:168-172.

19. Sarker MNI. An Introduction to Agricultural Anthropology: Pathway to Sustainable Agriculture. $J$ Sociol Anthropol. 2017;1:47-52.

20. Khan M, Zinnah M, Siddique M, Rashid M, Islam M, and Choudhury K. Physical and microbial qualities of raw milk collected from Bangladesh Agricultural University dairy farm and the surrounding villages. Bangladesh Journal of Veterinary Medicine, 2008;6: 217-221.

21. Islam MN, Hussain SMI, Mannan AKM. Studies on the physical parameters and chemical qualities on market milk in Mymensingh town (Bangladesh). Bangladesh Journal of Animal Science.1984;13 (1and2): 52-55.

22. Coitinho TB, Cassoli LD, Cerqueira PHR, da Silva HK, Coitinho JB, Machado PF. Adulteration identification in raw milk using Fourier transform infrared spectroscopy. J Food Sci Technol. 2017;54:2394-2402. 
23. Ghasemi-Varnamkhasti M, Ghatreh-Samani N, Naderi-Boldaji M, Forina $\mathrm{M}$, Bonyadian $\mathrm{M}$. Development of two dielectric sensors coupled with computational techniques for detecting milk adulteration. Comput Electron Agric. 2017;140:266278.

24. Farrell D. Status of poultry in global food products with special emphasis on the Asian Pacific Region. 2003;pp. 14-18.

25. Chanda T, Debnath GK, Hossain ME, Islam MA, Begum MK. Adulteration of raw milk in the rural areas of Barisal district of Bangladesh. Bangladesh $J$ Anim Sci. 2012;41:112-115.

26. Davidson PM, Roth LA and Gambrel-Lenarz JBSA. Tech. Comm. In Chapter 7 Coliform and Other Indicator Bacteria, Standard Methods for the Examination of Dairy Products. 2012;pp. 187-226, 17th ed. HM Wehr, JF Frank, edited: American Public Health Association, Washington, DC.

27. De Carvalho BMA, De Carvalho LM, Dos Reis Coimbra JS, et al. Rapid detection of whey in milk powder samples by spectrophotometric and multivariate calibration. Food Chem. 2015;174:1-7.

28. Clunie HWM, Harry H. Milk: Production and Control. Third Edition, H. K. Lewis and Co. Ltd. 1951;pp.122412

29. Akirul M. Detection of adulteration of raw milk collected from Muktagacha upazila of Mymensingh district. MS Thesis, Department of Dairy Science, Bangladesh Agricultural University, Mymensingh. 2012

30. Rashedul MD. Study on the quality evaluation and detection of adulteration of raw milk at Fulbaria upazila of Mymensingh district. MS Thesis, Department of Dairy Science, Bangladesh Agricultural University, Mymensingh. 2012

31. Lateef M, Faraz A, Mustafa MI, Akthar P and Bashir MK. Detection of adulterants and chemical composition of milk supplied to canteens of various hospitals in Faisalabad city. Pakistan Journal of Zoology, 2012;9:139-142.

32. Safi U. Study on the quality evaluation and detection of adulteration of raw milk at Mymensingh sadar upazila in Mymensingh. MS Thesis, Department of Dairy Science, Bangladesh Agricultural University, Mymensingh. 2012

33. Du L, Lu W, Cai Z (Julia), et al. Rapid detection of milk adulteration using intact protein flow injection mass spectrometric fingerprints combined with chemometrics. Food Chem. 2018;240:573-578.

34. Zia U. Improved market access and smallholder dairy farmer participation for sustainable dairy development. Consultancy Report CFC/FIGMDP/16FT. Lessons Learned Study. Islamabad, Pakistan. 2007
35. Monem PK. Quality of raw milk available at different markets of Bogra town. M. S Thesis, Department of Dairy Science, Bangladesh Agricultural University, Mymensingh. 2012

36. Bari AKM. Comparative study of platform tests on milk in the local markets and Bangladesh Agricultural University dairy farm. MS Thesis, Department of Dairy Science, Bangladesh Agricultural University, Mymensingh. 2001

37. Asaduzzaman. Detection of adulteration of milk collected from Bangladesh Agricultural University Dairy farm, Mymensingh and local markets, $M S$ Thesis, Department of Dairy Science, Bangladesh Agricultural University, Mymensingh. 2009

38. Mahedi H. Quality of raw milk available at different markets of Mymensingh town. MS Thesis, Department of Dairy Science, Bangladesh Agricultural University, Mymensingh. 2012

39. Liu J, Ren J, Liu ZM, Guo BH. A new comprehensive index for discriminating adulteration in bovine raw milk. Food Chem. 2015;172:251-256.

40. Lu W, Liu J, Gao B, Lv X, Yu L (Lucy). Technical note: Nontargeted detection of adulterated plant proteins in raw milk by UPLC-quadrupole time-of-flight mass spectrometric proteomics combined with chemometrics. J Dairy Sci. 2017;100:6980-6986.

41. Motta TMC, Hoff RB, Barreto F, et al. Detection and confirmation of milk adulteration with cheese whey using proteomic-like sample preparation and liquid chromatography-electrospray-tandem mass spectrometry analysis. Talanta. 2014;120:498-505.

42. Rahman AKM. A study on the physical and chemical qualities of milk collected from different plant of Bangladesh milk producers' Co-operative Union Ltd. (Milk Vita). M. S. Thesis, Department of Dairy Science, Bangladesh Agricultural University, Mymensingh. 1995

43. Salam AM. Studies on the physical, chemical and microbiological qualities of milk produced in Baghaban Milk shed Area. MS Thesis, Department of Dairy Science, Bangladesh Agricultural University, Mymensingh. 1993

44. Pantoja JCF, Reinemann DJ, Ruegg PL. Associations among milk quality indicators in raw bulk milk. Journal of Dairy Science, 2009;92:4978-4987.

45. Nascimento CF, Santos PM, Pereira-Filho ER, Rocha FRP. Recent advances on determination of milk adulterants. Food Chem. 2017;221:1232-1244.

46. Moncayo S, Manzoor S, Rosales JD, Anzano J, Caceres JO. Qualitative and quantitative analysis of milk for the detection of adulteration by Laser Induced Breakdown Spectroscopy (LIBS). Food Chem. 2017;232:322-328.

47. Herreid, E. O. 2008. The Babcock test; A Review of the literature. Journal of Dairy Science. 25:342-343. 